\title{
Population Health Adaptation Approaches to the Increasing Severity and Frequency of Weather-Related Disasters Resulting From our Changing Climate: A Literature Review and Application to Charleston, South Carolina
}

\author{
Jennifer Runkle ${ }^{1,2} \cdot$ Erik R. Svendsen $^{3} \cdot$ Mark Hamann $^{4} \cdot$ Richard K. Kwok $^{5} \cdot$ John Pearce $^{3}$
}

Published online: 8 November 2018

(C) Springer Nature Switzerland AG 2018

\begin{abstract}
Purpose of Review Recent changes in our planetary climate have and will continue to challenge historical knowledge and risk assumptions for weather-related disasters. While the public health community is rapidly working to develop epidemiological approaches and tools to mitigate and adapt to these weather-related disasters, recent high-profile events have exposed gaps in knowledge and response efforts. Limited work has been done to assess the climate readiness of the local public health and healthcare community as it pertains to local response planning and adaptation measures in the event of a weather-related disaster. The purpose of this paper is to review the existing literature related to climate change, weather-related disasters, and population health approaches to adapt to climate-related changes in weather-related disasters at the local level. We highlight a brief case study to illustrate an example of a local approach to adaptation planning in a coastal community.

Recent Findings Few studies have put forth quantitative disaster epidemiology tools to aid public health officials in preparing for and responding to these weather-related disaster events. There is a general lack of understanding within the public health community about the epidemiological tools which are available to assist local communities in their preparation for, response to, and recovery from weather-related disasters.

Summary Cities around the nation are already working to assess their vulnerability and resilience to weather-related disasters by including climate change in emergency preparedness plans and developing adaptation strategies, as well as equipping local hospitals, health departments and other critical public health systems with climate information. But more work is needed and public health funding is lagging to support local and state-level efforts in preparing for and adapting to weather-related disasters in the context of a changing climate. Our population health disaster preparedness programs need to be adapted to address the increasing risks to local public health resulting from our changing climate.
\end{abstract}

This article is part of the Topical Collection on Global Environmental Health and Sustainability

Jennifer Runkle

jrrunkle@ncsu.edu; Jennifer.runkle@noaa.gov

1 North Carolina State University, Raleigh, NC, USA

2 Cooperative Institute for Climate and Satellites-North Carolina (CICS-NC) at NOAA's National Centers for Environmental Information (NCEI), North Carolina State University, 151 Patton Avenue, Asheville, NC 28801, USA

3 Environmental Health Department of Public Health Sciences, Medical University of South Carolina, Charleston, SC, USA

4 Department of Drug Discovery and Biomedical Sciences, Medical University of South Carolina, Charleston, SC, USA

5 Epidemiology Branch, National Institute of Environmental Health Sciences, Research Triangle Park, NC, USA
Keywords Climate change $\cdot$ Weather-related disasters $\cdot$ Public health · Adaptation $\cdot$ Healthcare system resiliency

\section{Introduction}

Global Climate Change The impacts of climate change have taken center stage as a leading twenty-first century threat to the Nation's health. A global assessment of climate change revealed an overall average temperature increase of about $1.8^{\circ} \mathrm{F}$ since 1880 . [1,2] With the increased temperature of the earth's surface, air and water temperatures have also increased leading to the heightened intensity and frequency of precipitation, storms, hurricanes, floods, droughts, and associated wildfires [3-9]. Future changes in climate are expected to increase the intensity and frequency of some extreme events, such as tropical cyclones, heat waves, flooding, 
drought, and associated wildfires [2]. The planet has also seen reductions in frost days, snow cover, and glaciers [8-10]. One of the greatest concerns related to climate change is the risk associated with the Global Mean-Sea Level Rise (GM-SLR) [11]. The USA is not immune to this threat [12]. In the Southeastern US, the average temperature has risen around $2{ }^{\circ} \mathrm{F}$ since 1970 and climate models predict an increase in the rate of warming from now to the end of the century [13]. A recent report published in Nature by DeConto and Pollard suggests that current projections grossly underestimate the potential for future GM-SLR indicating that past polar temperatures just slightly warmer than today resulted in sea levels 6-9 m higher than current levels [14]. Revised projections based on modeling of the Antarctic ice sheet and climate dynamics suggest that Antarctica could contribute more than a meter of GMSLR by 2100 and $15 \mathrm{~m}$ by 2500 under current models [14]. The data are certain - the climate is changing $[8,15,16]$.

Weather-Related Disasters A recent Working Group II report of the Intergovernmental Panel on Climate Change cautions that low-lying coastal areas are increasingly vulnerable to the effects of sea level rise, storm surge, flooding, and extreme storm events $[2,8]$. It is anticipated that these flooding events will have an indirect effect on human health by placing continual stress on the healthcare system. Low-lying coastal areas and the health care systems serving these areas are particularly vulnerable to flooding due to limited investments in shortterm emergency response and a lack of capacity to respond promptly and efficiently in the event of a climate-related weather disaster [17]. It is well known that public health systems should prepare for weather-related extreme events as a significant threat to human health and well-being, particularly among vulnerable coastal communities. Events such as Hurricanes Katrina (2005), Sandy (2012), and Harvey (2017) have served as examples of how devastating such weather-related disasters can be on the local population and on the healthcare systems that serve them. Recent changes in our planetary climate have and will continue to challenge historical knowledge and risk assessment of weather-related disasters [17-19]. Hospitals and public health programs in coastal communities will need to expand their "all hazards" approach to address a wide variety of potential climate-related impacts, including short- and long-term disruptions to essential health services delivery following extreme events.

Global Mean Sea-Level Rise The increasing GM-SLR is particularly threatening for barrier islands and other low-lying coastal areas in the USA. The extensive chain of barrier islands along its eastern coast are highly vulnerable to GMSLR as reported in the NOAA Technical Report NESDIS 142$2[20,21]$. Projections of GM-SLR by the end of this century indicate partial inundation of some areas of the southeastern coast [22]. The barrier islands and other coastal low lying regions are also highly susceptible to storms and hurricanes from the Gulf of Mexico and Atlantic Ocean. Unfortunately, the destructive potential of hurricanes has increased since 1970 and is likely to continue to increase in this century with higher rainfall intensity and strength $[23,24]$. Hurricanes and storms have become more intense in the coastal low country of the south, and these areas will suffer inundation as the sea level rises [12, 25, 26]. Hurricane Matthew impacted the southeast coast causing significant damage from Florida to North Carolina bringing large waves and storm surge to the shoreline, flooding some coastal areas. The impact of this hurricane has been evaluated by USGS National Assessment of Coastal Change Hazard Storm Team and the projected erosion along the east coast is shown in Fig. 1 [17].

Coastal Vulnerability to Extreme Events Extreme weather events along the coast are expected to significantly increase in number and intensity during the twenty-first century due to sea-level rise caused by climate change and more frequent and extreme precipitation and coastal storm surge events $[2,26]$. Coastal communities are increasingly vulnerable to flooding due to the effects of climate change, which is further exacerbated by development in hazard prone areas and rapid population growth. More than $50 \%$ of the US population now lives in low-lying coastal areas [27], and these coastal counties generate about $56 \%$ of all national economic output [28]. The Southeast has experienced unprecedented coastal population growth in recent decades [27]. An estimated 10 million more Americans are expected to live in coastal shoreline counties by 2020 [29]. Coastal areas are more vulnerable to extreme events due to a combination of risks, including social vulnerability, a lack of preparedness, and increased exposure to climate change drivers associated with extreme events (Fig. 2). These events will adversely impact human health and serve as episodic and chronic stressors on health service delivery and continuity of care.

Heavy Precipitation and Health Impacts There are multiple "exposure" pathways by which adverse health outcomes may arise before, during, and after a coastal flooding event, including (1) hazards of storm exposure (e.g., wind), (2) population and hospital evacuation, (3) poststorm secondary hazards (e.g., power outage), (4) population displacement and health care disruption, (5) mental health and stress-related disorders, and (6) clean-up and recovery work hazards [30]. Epidemiological and public health research have shown differential vulnerability to flood exposure in some communities, with health effects ranging from short to longer term, direct and indirect [31]. Short-term health outcomes of flooding events include drowning and acute-trauma related deaths, injuries, toxic exposures, and water-related (e.g., gastrointestinal illness) $[32,33]$ and vector-borne disease [34]. The longer-term 
Fig. 1 UUSGS National Assessment of Coastal Change Hazards project forecasts for coastal erosion along the Florida coastline to North Carolina in response to Hurricane Matthew. Source: https://marine.usgs.gov/ coastalchangehazardsportal/ui/ item/ELxk5wv5

\section{DUSGS Coastal Change Hazards Portal All- Seachum}

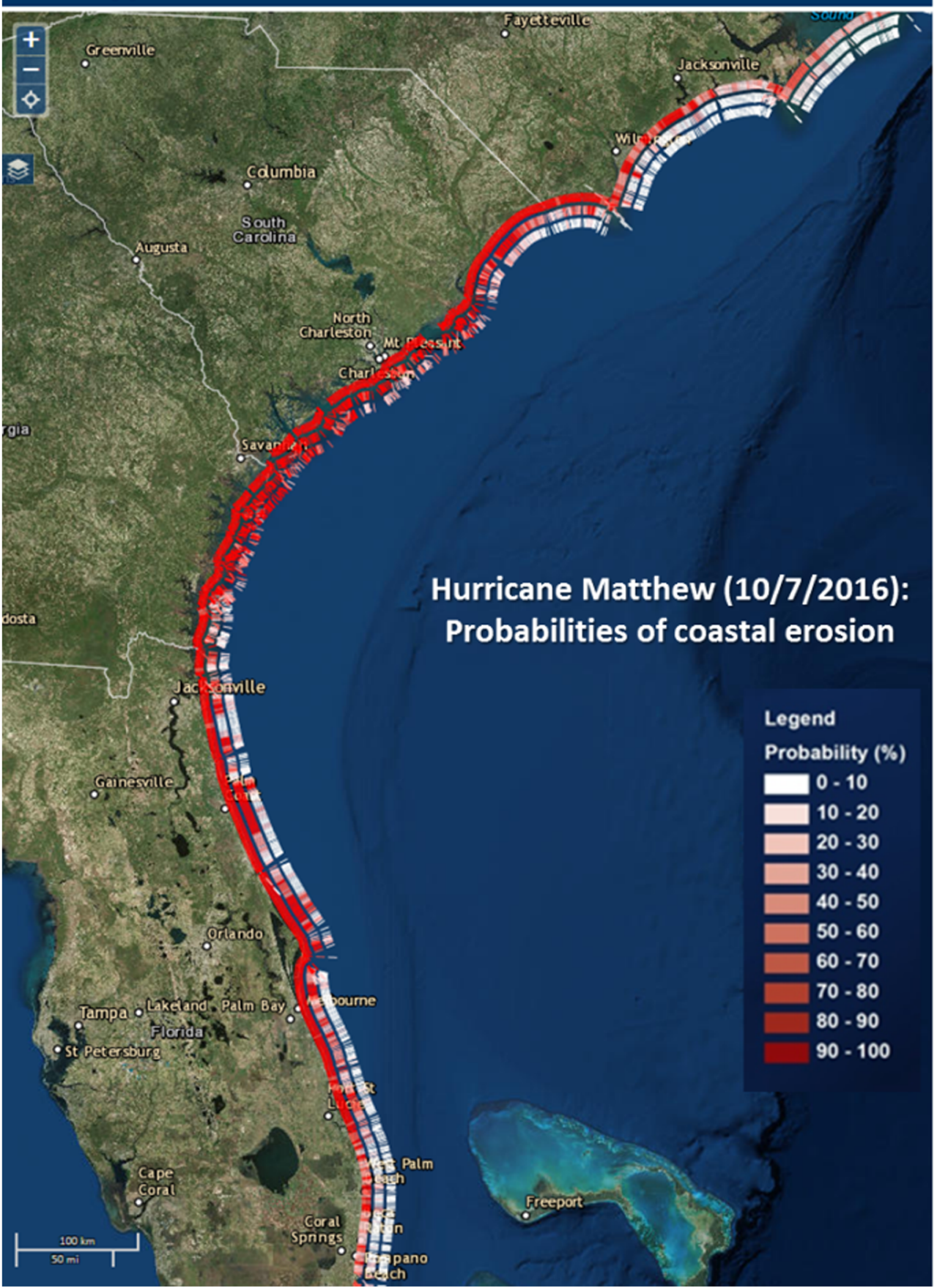

impacts of floods are complex and not well understood, but may include the exacerbation of chronic illnesses, stress, and mental health consequences (e.g., PTSD, anxiety, and depression), and poor birth outcomes (e.g., low birth weight and preterm delivery) [35].

\section{Weather-Related Disasters and the Healthcare System} Healthcare systems are front-line defenders of the population's health and key partners within the public health protection system. Climate change threatens the quality and continuity of care provided by healthcare systems due to more frequent and extreme weather events and increased health risks from climate hazards. Coastal flooding events are expected to increase in number and intensity in the future due to sea-level rise caused by climate change and more frequent and extreme precipitation events. Hospitals in coastal areas will need to expand their "all hazards" approach to address a wide variety of potential climate-related health impacts, 


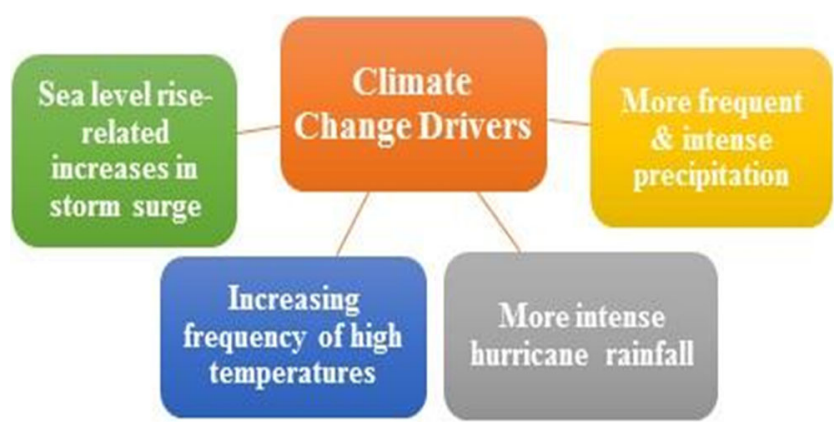

Fig. 2 Climate change drivers of weather-related disasters in coastal communities

including the disruption of necessary health services. In response to a changing climate, coastal cities are increasingly vulnerable to flooding during hurricanes and other severe storms. These events will adversely impact human health and lead to disruptions in health service delivery and continuity of care. There has been considerable effort describing the need for resilient health care systems in the wake of weather-related disasters associated with our changing climate [16, 36-38, 39••, 40••, 41, 42]. Yet, little work has been done to assess the climate readiness of the public health and healthcare community as it pertains to medical surge capacity during weather-related disasters [43].

\section{Extreme Weather Events and Healthcare System Performance}

The indirect, and in some cases longer-term, health impacts following flooding and other extreme events often involve an increased demand in patient care and subsequent reduced surge capacity of local and regional hospital systems. Interruptions to medical services delivery following coastal storms and flooding, such as Hurricane Sandy, have been associated with exacerbation of chronic health conditions (both physical and mental) and increased demand for acute care medical supplies (e.g., prescription medications, oxygen) [44-47]. Public health protection depends on reducing vulnerabilities and enhancing climate resilience of critical infrastructure and other services. In addition, anticipating the health impact for the affected population, with specific focus on the performance of the healthcare system before, during, and after an event, is crucial. Extreme events may exacerbate ongoing pressures and vulnerabilities within healthcare systems because these health systems may be operating at maximum capacity, may attract a disproportionate share of chronically ill and low-income persons, and may be ill-prepared for a mandatory patient evacuation or patient surge following a climate-related extreme event.

Communities depend on hospitals to provide essential services at all times, under any circumstances. Climate change threats place hospitals and those life-saving services at risk. As such, hospital preparedness planning and climate resilience measures must be put in place to reduce post-event morbidity and mortality in the affected population. For example, a New Jersey hospital demonstrated the importance of a decade of emergency preparedness planning to ensure health system performance in the event of Hurricane Irene in 2011 [48]. Resilience measures are especially important for vulnerable coastal hospitals situated in flooding prone, low-lying areas. However, priority has not been given to coastal hospital preparedness and resilience measures, especially for climate vulnerable facilities and functions. Further, the health care community generally lacks climate data surveillance efforts, as well as the expertise to critically evaluate these data, necessary to adequately plan and prepare for these climate hazards and hospital-associated vulnerabilities.

Hospital Vulnerability Assessments Each year, the Joint Commission requires that hospitals complete a hazard vulnerability analysis (HVA) to lay the groundwork for emergency preparedness efforts. While all hospitals are expected to develop, implement, and conduct training exercises using an allhazards emergency preparedness framework, there is no standardized method or tool for performing these HVAs. Kaiser Permanente developed a Hazard Vulnerability and Assessment Tool for Medical Center Hazard and Vulnerability Analysis that is most often used among healthcare systems [49]. Yet, individual hospitals are left to decide how they will collect data on the probability or severity of a particular hazard, as well as how they will process that information and interpret findings at the institutional level. For example, a recent study examining the implementation of HVAs in Maine found significant hospital-to-hospital variability in the HVA process, including cross-institutional variation in the scoping of risks (limited versus expanded view), clarification concerning the time frame of preparedness planning (shorter- versus long-term), and the level of resources dedicated toward an HVA were directly related to the commitment of senior leaders [50]. Furthermore, the study identified significantly different results on how an HVA influenced institutional-level preparedness activities and in many cases the results of the HVA process were not widely disseminated among hospital staff. HVAs performed by hospitals are typically focused on infrastructure impact, and to our knowledge, no HVAs incorporate the impact of climate change or variability on subsequent changes in the severity and frequency of particular "hazard" events. There is a critical gap in the HVA process concerning a more standardized approach to the scoping of risks that include climate-related changes, the focus on the public health impact of these risks, and the integration of expert input from community experts in public health and emergency management. We are unaware of any published study which has assessed this issue.

Framing Risk and Vulnerability in the Context of the Health System Response to Climate Change Healthcare systems are front-line defenders of the population's health and they play a key role in community resilience. Conditions that contribute 
Table 1 Key terms used in framing risk and vulnerability of health care system to climate change

\begin{tabular}{cc}
\hline Climate change & $\begin{array}{c}\text { a change in the state of the climate that can be identified by changes in the mean and/or } \\
\text { variability of its properties and that persists for an extended period (decades or longer) [8] }\end{array}$ \\
\hline Vulnerability & $\begin{array}{c}\text { The propensity to be adversely affected by climate-related health effects and is a function } \\
\text { of three key elements - exposure, sensitivity, and adaptive capacity [8] }\end{array}$ \\
$\begin{array}{c}\text { Hospital } \\
\text { preparedness } \\
\text { Health system } \\
\text { resilience }\end{array}$ & $\begin{array}{c}\text { The ability of the health care system to prepare, respond, and recover from incidents that } \\
\text { changing shape of risk before adverse consequences occur [52] }\end{array}$ \\
$\begin{array}{c}\text { Medical surge } \\
\text { capacity }\end{array}$ & $\begin{array}{c}\text { The ability to provide adequate medical evaluation and care for an increased volume of } \\
\text { patients during incidents that exceed the normal operating capacity [53] }\end{array}$ \\
\hline
\end{tabular}

to a community's climate and weather vulnerabilities are varied and change over time, requiring continual and broad-based planning to understand the social, environmental, and institutional challenges to effective health system preparedness and response. Essentially, the health risk to the population from climate as a threat is directly dependent on the type of climate threat, the resilience of the health system, and ability of the health system to withstand that specific threat as defined in Table 1 [52]. Preparedness is composed of both vulnerability (system protection) and resilience (system recovery). For example, system vulnerability can be reduced by preparing for changes in medical surge capacity before an event and system resilience can be improved by preparing for increases in service need after the event; thereby strengthening the health system's overall preparedness to an extreme event. This is contingent upon the capacity of the healthcare community to organize itself and minimize impacts before an event.

Purpose As the frequency of weather-related disasters has increased, so has the development of public health and epidemiological approaches to mitigate and adapt to those disasters $[38,39 \bullet \bullet, 54-65,66 \bullet, 67]$. Recent high-profile incidents have exposed gaps in knowledge about the health impacts of disasters or the benefits of specific interventions. Much of the public health dialog regarding climate change and its impact on human health has been focused on large-scale mitigation strategies to reverse the trends in climate change. However, the impacts of climate change are local, real, and have already arrived. Therefore, it may be more prudent for local population health professionals to focus their public health preparedness efforts on the local adaptation strategies which they could enact practically rather than local mitigation strategies which may not be as effective at addressing the larger global climate change patterns alone and are agnostic to the increasing local impacts of climate change which have already arrived. The purpose of this paper is to review the existing literature related to climate change, weather-related disasters, and population health approaches to adapt to the changing climate and weather-related disasters. Population health adaptation approaches include the public sector (public health-affiliated agencies) and private sector (healthcare and hospital system) strategies. A brief case study is included to illustrate an example of a local approach to adaptation planning to promote population health.

\section{Methods}

Literature Review Methods Comprehensive literature reviews have been recently performed to assess the current state of the science regarding climate change $[2,8]$, associated adverse health outcomes from weather-related disasters $[15,16,38$, $39 \bullet \bullet, 68,69]$, public health disaster research [70, 71], and disaster epidemiology [72]. However, we are unaware of any systematic literature review of the intersections between climate change, adverse weather-related disasters, and population health adaptation strategies. Herein we performed more focused literature reviews to highlight the key connections between climate change, weather-related disasters, and population health adaptation strategies.

Electronic literature searches were performed for the following topics and with the following limitations using the PubMed internet literature search engine [73]: climate change, weather-related disasters, and population health. The population health search includes two specific literature searches. First, the terms "disaster" + "epidemiology" + "tool" were searched within the abstract and limited to English-language articles resulting in 68 articles between 2008 and 2018 . Second, the terms "climate change" + "adaptation" were used to further discriminate our findings. Disasters which were not weather-related were excluded. Of the 68 articles identified, the 10 papers most directly focused on our search terms were reviewed [74-83]. Many of those articles focused on mental health outcomes related to disasters. Others focused on assessing nutrition status within populations impacted by such events. Others focused on pandemic influenza planning or on foodborne outbreaks. Some discussed health communication tools within this context. In addition, we performed a geospatial analysis for Charleston County to examine the sensitivity of MUSC and surrounding healthcare facilities to varying sea-level rise-related flood exposure scenarios. 
Table 2 Overview of 10 practical disaster tools that can be used by public health officials

\begin{tabular}{|c|c|c|c|}
\hline Tool & Application & Objective & Guidance domain \\
\hline $\begin{array}{l}\text { Public health capabilities } \\
\text { performance measurement } \\
\text { tool }[74]\end{array}$ & Table-top exercises & $\begin{array}{l}\text { Measure public health functional } \\
\text { capabilities in a tabletop exercise } \\
\text { setting }\end{array}$ & $\begin{array}{l}\text { Disease control and prevention; } \\
\text { surveillance; mass care; leadership } \\
\text { and management; public health } \\
\text { system communication }\end{array}$ \\
\hline $\begin{array}{l}\text { Regional public health } \\
\text { emergency preparedness for } \\
\text { cross-border public health } \\
\text { preparedness [75] }\end{array}$ & Checklist & $\begin{array}{l}\text { Assess regional public health } \\
\text { emergency preparedness, } \\
\text { specifically in regard to cross-border } \\
\text { public health preparedness needs }\end{array}$ & $\begin{array}{l}\text { Recommends } 24 \text { specific agreements, } \\
\text { protocols, systems, and management } \\
\text { structures that should be considered } \\
\text { to foster cross-border public health } \\
\text { preparedness }\end{array}$ \\
\hline $\begin{array}{l}\text { Multiplying factor (MF) as a } \\
\text { predictive tool during mass } \\
\text { casualty incident (MCI) [76] }\end{array}$ & $\begin{array}{l}\text { Decision-making tool to anticipate } \\
\text { the need for ambulance and life } \\
\text { support resources }\end{array}$ & $\begin{array}{l}\text { Evaluate the usefulness of a multiplying } \\
\text { factor in estimating final number of } \\
\text { victims in these types of events: } \\
\text { explosions, fire, and road traffic } \\
\text { accidents }\end{array}$ & $\begin{array}{l}\text { Predicting mortality after MCI } \\
\text { accounting for under-reporting bias }\end{array}$ \\
\hline $\begin{array}{l}\text { Evaluation of environmental } \\
\text { and epidemiological risk } \\
\text { factors during the } \\
\text { emergency through a } \\
\text { crowdsourcing tool [77] }\end{array}$ & $\begin{array}{l}\text { Ad hoc web/mobile website } \\
\text { created on the } \\
\text { Ushahidi/Crowdmap platform }\end{array}$ & $\begin{array}{l}\text { Describe main environmental risk } \\
\text { factors in the emergency process } \\
\text { after a large urban fire }\end{array}$ & $\begin{array}{l}\text { Environmental risk factors for damaged } \\
\text { infrastructure, vectors, and garbage }\end{array}$ \\
\hline $\begin{array}{l}\text { Mass-gathering triage tool for } \\
\text { first responders [78] }\end{array}$ & $\begin{array}{l}\text { Australian mass-gathering triage } \\
\text { tool during clinical assessment } \\
\text { and management of patients }\end{array}$ & $\begin{array}{l}\text { Describe the development of a } \\
\text { mass-gathering triage tool for use by } \\
\text { first responders in Australia }\end{array}$ & $\begin{array}{l}\text { Categories included: resuscitation; } \\
\text { urgent; minor; self-help }\end{array}$ \\
\hline $\begin{array}{l}\text { Tool to assess long term public } \\
\text { health effects of earthquakes } \\
\text { [79] }\end{array}$ & $\begin{array}{l}\text { GIS-based tool for assessing } \\
\text { long-term effects of a disaster on } \\
\text { childhood stunting }\end{array}$ & $\begin{array}{l}\text { Explored whether long-term public } \\
\text { health effects of earthquakes can be } \\
\text { assessed using a combination of } \\
\text { readily available data sources on } \\
\text { public health and geographic } \\
\text { distribution of seismic activity }\end{array}$ & Long-term public health effects \\
\hline $\begin{array}{l}\text { Measuring impact of sectoral } \\
\text { response: post-tsunami [80] }\end{array}$ & $\begin{array}{l}\text { Framework on durable solutions } \\
\text { for internally displaced persons } \\
\text { Impact measurement tool }\end{array}$ & $\begin{array}{l}\text { Performed impact assessment of } \\
\text { humanitarian services rendered in } \\
\text { Aceh using a comprehensive set of } \\
\text { rights-based indicators and } \\
\text { determined modifiable predictors of } \\
\text { improved outcomes in } \\
\text { disaster-affected households }\end{array}$ & $\begin{array}{l}\text { Pre-tsunami conditions; tsunami } \\
\text { damages; displacement; assistance } \\
\text { received }\end{array}$ \\
\hline $\begin{array}{l}\text { Surveillance of injuries } \\
\text { post-hurricane in North } \\
\text { Carolina [81] }\end{array}$ & $\begin{array}{l}\text { North Carolina Disease Event } \\
\text { Tracking and Epidemiologic } \\
\text { Collection Tool (NC Detect) } \\
\text { data to estimate } \\
\text { hurricane-associated injuries }\end{array}$ & $\begin{array}{l}\text { Characterized non-fatal injuries, by age } \\
\text { groups, that were seen in emergency } \\
\text { departments (EDs) in } 29 \text { selected } \\
\text { counties in Eastern North Carolina } \\
\text { following Hurricane Irene }\end{array}$ & $\begin{array}{l}\text { Derive estimate for common injuries } \\
\text { observed in emergency departments } \\
\text { in acute phase of natural disaster }\end{array}$ \\
\hline $\begin{array}{l}\text { Respiratory and mental health } \\
\text { effects of wildfires: an } \\
\text { ecological study [82] }\end{array}$ & $\begin{array}{l}\text { Ecological geographical- and } \\
\text { temporal-cluster study on } \\
\text { anxiolytics-hypnotics and drugs } \\
\text { for obstructive airway diseases } \\
\text { consumption }\end{array}$ & $\begin{array}{l}\text { Analyzed the respiratory and mental } \\
\text { health effects of the August } 2006 \\
\text { fires, using consumption of } \\
\text { anxiolytics-hypnotics and drugs for } \\
\text { obstructive airway diseases as } \\
\text { indicators }\end{array}$ & $\begin{array}{l}\text { Research on drug use is a useful tool for } \\
\text { studying morbidity associated with } \\
\text { environmental impacts post-disaster }\end{array}$ \\
\hline $\begin{array}{l}\text { Preserving lessons learned in } \\
\text { disease outbreaks and other } \\
\text { emergency responses [83] }\end{array}$ & $\begin{array}{l}\text { Steps to take pre-, during, and } \\
\text { post-event to preserving } \\
\text { information }\end{array}$ & $\begin{array}{l}\text { Explored the process of studying } \\
\text { disaster events by gathering, } \\
\text { preserving and presenting data }\end{array}$ & $\begin{array}{l}\text { Pre-event: identify and meet with } \\
\text { stakeholders; establish consensus on } \\
\text { importance of lessons learned; } \\
\text { identify needed skills and resources; } \\
\text { create writing protocols for } \\
\text { preserving information; create } \\
\text { agreements and relationships with } \\
\text { stakeholders } \\
\text { Post-event: gather post-event data; } \\
\text { analyze and consolidate/disseminate } \\
\text { in practical way }\end{array}$ \\
\hline
\end{tabular}




\section{Results}

Table 2 provides an overview of the 10 key papers reviewed that focused on practical disaster epidemiology tools which were relevant to this context [74-83]. Jones et al. introduced a tool to assess impacts of these types of events within public health preparedness planning for cross-border issues [75]. Savoia et al. assessed the efficacy of different tools within tabletop exercises [74]. Maurin et al. developed a strategy to calibrate mortality data due to under-reporting biases [76]. Espinoza et al. developed an innovated web-based query tool to assist with data collection within disasters [77]. Cannon developed a robust triage tool which is applicable to mass casualties within a disaster setting [78]. Rydberg et al. developed a tool to assess the long-term adverse health effects of natural disasters [79]. Lee et al. developed an epidemiological survey tool designed for use within disaster settings [80]. Miller et al. developed a similar survey tool for surveillance within emergency departments during disasters [81]. Caamano-Isorna et al. developed an epidemiological tool for wildfire disasters [82]. Lastly, Stebbins et al. developed a method for systematically collecting the lessons learned from public health disasters [83].

Case-Study Population Our case study area, the City of Charleston, is one of the most vulnerable metropolitan areas along the East Coast to climate-related coastal threats, including sea-level rise and tidal flooding [84]. The Medical University of South Carolina (MUSC) in Charleston is the case hospital facility. MUSC is South Carolina's only comprehensive academic medical center with a service area of about 700,000 people in the Charleston metropolitan area. As a tertiary/quaternary hospital, MUSC receives physician referrals from all over the state and beyond for the most complex surgeries, specialized services, and treatment for the sickest of patients. MUSC is a 700-bed medical center that records over 1 million patient encounters annually.

Sea-level rise is an important concern in the Charleston area due to its extensive coastline. Historically, sea level has risen on average $1.2 \mathrm{in}$. per decade for the state and recent projections show the Atlantic has the potential to rise an additional $5 \mathrm{ft}$ by $2100[2,85]$. Today, more than $800 \mathrm{mi}^{2}$ of coastal land near the Charleston area lie less than $4 \mathrm{ft}$ above the high-tide line in South Carolina. Even marginal amounts of sea-level rise increase the likelihood of nuisance flooding events (flooding which causes public inconvenience) by amplifying high tide and storm surge levels. As a result, high tides continue to exceed historic observations and these extreme high tides have been associated with more frequent nuisance flooding events. For example, 2010 predictions relying on regular cycle of moon phases showed that Charleston would experience five flood-producing high tides (defined as $7 \mathrm{ft}$ or higher). These predictions did not account for extreme precipitation events or onshore winds, resulting in an observed 19 high-tide flooding events [86]. Charleston is representative of other coastal communities in the Southeast and around the nation who have experienced large increases in nuisance flooding events since the 1980s [87].

In addition to sea-level rise, storm surge during hurricanes exacerbates coastal flooding. Between 1901 and 2009, a total of 27 tropical cyclones made landfall along the South Carolina coast, eight of which were of category 2 to category 4 intensity. The most notable of these was Hurricane Hugo in 1989, which made landfall on the northern side of Charleston Harbor as a powerful category 4 storm. It produced storm surge and storm tides above 10 to $12 \mathrm{ft}$ (compared to MSR) near the Charleston harbor [88, 89]. Hugo is the costliest storm in Charleston's history, with damages surpassing $\$ 6$ billion for the city and $\$ 33$ million for MUSC. A total of 35 hurricaneassociated deaths in South Carolina followed in the 2 weeks after Hugo, $22(45 \%)$ of which occurred during the postimpact phase as a result of trauma-related injuries (e.g., electrocution, use of candles and/or open flames for a light or heating source, and occupational injury during clean-up) [90]. Reports of 2090 emergency department visits in the 2 weeks after the storm also revealed substantial morbidity inland in North Carolina, whereby 8 out of 10 were related to insect stings or wound injuries [91]. A high burden of psychological distress (i.e., anxiety, depression, mental distress, and post-traumatic stress disorder) among those directly exposed was observed 3 months post-Hugo in children [92], up to 1 year later in adolescents [93], and 24 months post-event in adults [94].

In early October 2015, torrential rainfall caused catastrophic flooding. The rainfall broke a long drought period and shattered numerous 24-h and 5-day total rainfall records. The state's standing 24-h rainfall record of 14.8 in. set during Hurricane Floyd in Myrtle Beach (September 16, 1999) was broken at White Birch Circle in Columbia, which recorded a 24-h total of $17.7 \mathrm{in}$. on October 4, with $15.1 \mathrm{in}$. falling in less than $10 \mathrm{~h}$ in the morning hours. The previous record wettest 5 day period of 17.4 in. (Greenville, August 22-26, 1908) was broken at more than 40 locations, with the largest amounts being recorded at Mount Pleasant (Park West) with 27.2 in. (October 2-6), Charleston (Clark Sound) with 23.8 in. (October 1-5), Georgetown County Airport with 23.5 in. (October 1-5), Charleston (James Island) with 22.0 in. (October 2-6), and Folly Beach with 21.5 in. (October 2-6).

On October 8, 2016, Hurricane Matthew made landfall producing tide levels at the Charleston Harbor at their third highest level on record since Hugo and over a foot higher than the early October 2015 flood event (NWS 2016). Hurricane Matthew-associated deaths across four states (Florida, Georgia, North and South Carolina) totaled to 43, the majority of which occurred in North Carolina $(n=26,60 \%)$ and were directly associated with drowning in a motor vehicle $(n=18$, 
69\%) (e.g., vehicle driven into standing water, vehicle swept away by water) [95]. Delayed outbreaks of vector-borne diseases are typically observed about 8 weeks post-hurricane [96] and the threat of a Zika outbreak was of particular concern for Florida after Matthew [97]. Disruptions in vector control measures and public awareness campaigns around Zika recently appropriated by Congress ( $\$ 1.1$ billion US dollars) were diverted to deal with the acute public health response to the storm. In future events, public health authorities should consider implementing pre-planned mosquito-control measures combined with public awareness messaging campaigns to mitigate the potential for a surge in incident vector-borne disease cases [97].

In September 2017, Charleston received dramatic flooding due to Hurricane Irma (category 4 storm) also. Public health officials identified 129 hurricane-associated deaths from Florida, Georgia, and North Carolina in response to Irma and 115 were indirectly related to the event. A large proportion of deaths during Irma was related to exacerbation of preexisting medical conditions or power-outage-related death $(n=46,36 \%)$ and fell into the two sub-categories of a heatrelated or oxygen-dependent death [58]. More research is needed to systematically examine and categorize hurricaneassociated deaths into standardized sub-categories to assess specific circumstances surrounding disaster mortality and design more responsive public health interventions and mass media campaigns.

More recently, the Carolinas were impacted by Hurricane Florence, a category 4 storm that was downgraded to a category 1 by the time that it made landfall on September 17, 2018. Wind gust peaked at $105 \mathrm{mph}$ along the coast of North Carolina in Wilmington and wind was the driving factor behind storm surge across the entire coasts of both Carolinas. For example, surge levels reached $3.75 \mathrm{ft}$ as far away as Beaufort South Carolina, a threshold point in which local inundation typically occurs. What was particularly unique about this storm was the unusually slow pace in which it was moving causing record-breaking rainfall occurring over a 4-day period across the coast of the Carolinas. Data on total accumulation of rainfall and other storm-related public health impacts (e.g., death toll is 51) are preliminary, but Florence has quite possibly set a new record for rainfall totals for both North Carolina and South Carolina [98].

A few weeks after the Carolinas were impacted by Florence, Hurricane Michael (category 4 storm) made landfall in the Florida Panhandle on October 10, 2018. Michael is the strongest tropical cyclone to hit the USA since Hurricane Andrew and the strongest on record to affect the Florida Panhandle. After 2 days of heavy rainfall ranging from 5 in. in the Triad and up to 8 in. in the mountains of North Carolina, the storm is expected to produce additional flooding and flash flooding in the Carolinas, more than $400 \mathrm{mi}$ from where the storm initiated [99].
Charleston's history with Hurricane Hugo and the recent extreme rainfall events makes it an ideal case study setting. Results from our case-study assessment demonstrated that over 68 healthcare facilities would be impacted given a 4-ft increase in sea-level rise (Fig. 3, Table 3), resulting in a potential loss of over 4000 beds and 25,000 employees, severely reducing the MUSC health system to provide care. State-level estimates project a rise of $3.9 \mathrm{ft}$ by 2100 from a 2012 baseline after accounting for local effects of coastal land subsidence. In the future, the occasional coastal floods are expected to become regular events $[2,8,26]$.

\section{Discussion}

The climate on our planet has changed dramatically over time $[2,8]$. There is so much evidence of such changes that it is a commonly understood fact within the earth sciences community that the climate on earth has changed, is changing, and will continue to change. Within the past 30 years, we have seen rapidly increasing changes in global temperature and many other associated climatic effects. These measured weather data are sound and irrefutable. However, there has been fractious debate within politics over the explanation of these data or if they are even real because they are so abnormal. Herein we will not engage within the climate change debate. We will simply reiterate the facts demonstrated with the recorded weather data that the global climate is changing, and warming at a pace which is unprecedented in the past millennium. Such changes in the global climate have had immense influences on public health. In brief, global climate change is real, is happening, is documented, and we in public health need to be prepared for the threats to public health from it, especially weather-related natural disasters.

The latest IPCC report [100] cautions that we are already seeing the negative effects of $1{ }^{\circ} \mathrm{C}$ increase of warming globally demonstrated by more extreme weather events and rising sea levels. The report goes on to say that a "rapid and farreaching" transition over the next decade is required to move from the previously accepted $2{ }^{\circ} \mathrm{C}$ increase in global warming to $1.5^{\circ} \mathrm{C}$ to make sustainable reductions in the health-harming and planetary ills of climate change. We are seeing global changes in weather-related disasters concurrently with the changes in global temperature. The data are clear. The number and severity of weather-related disasters has increased within the same time interval during which the global climate has been changing. Therefore, there is ample scientific evidence to conclude that global changes in climate have caused global changes in the frequency and duration of weather-related natural disasters. Often public health programs are built on the faulty assumption of predictive normalcy, that the public health threats that we have faced in the past will be faced the same way in the future (e.g., 100-year flood). Therefore, 
Fig. 3 MUSC and surrounding health care facilities after the projected 4-ft increase in GMSLR

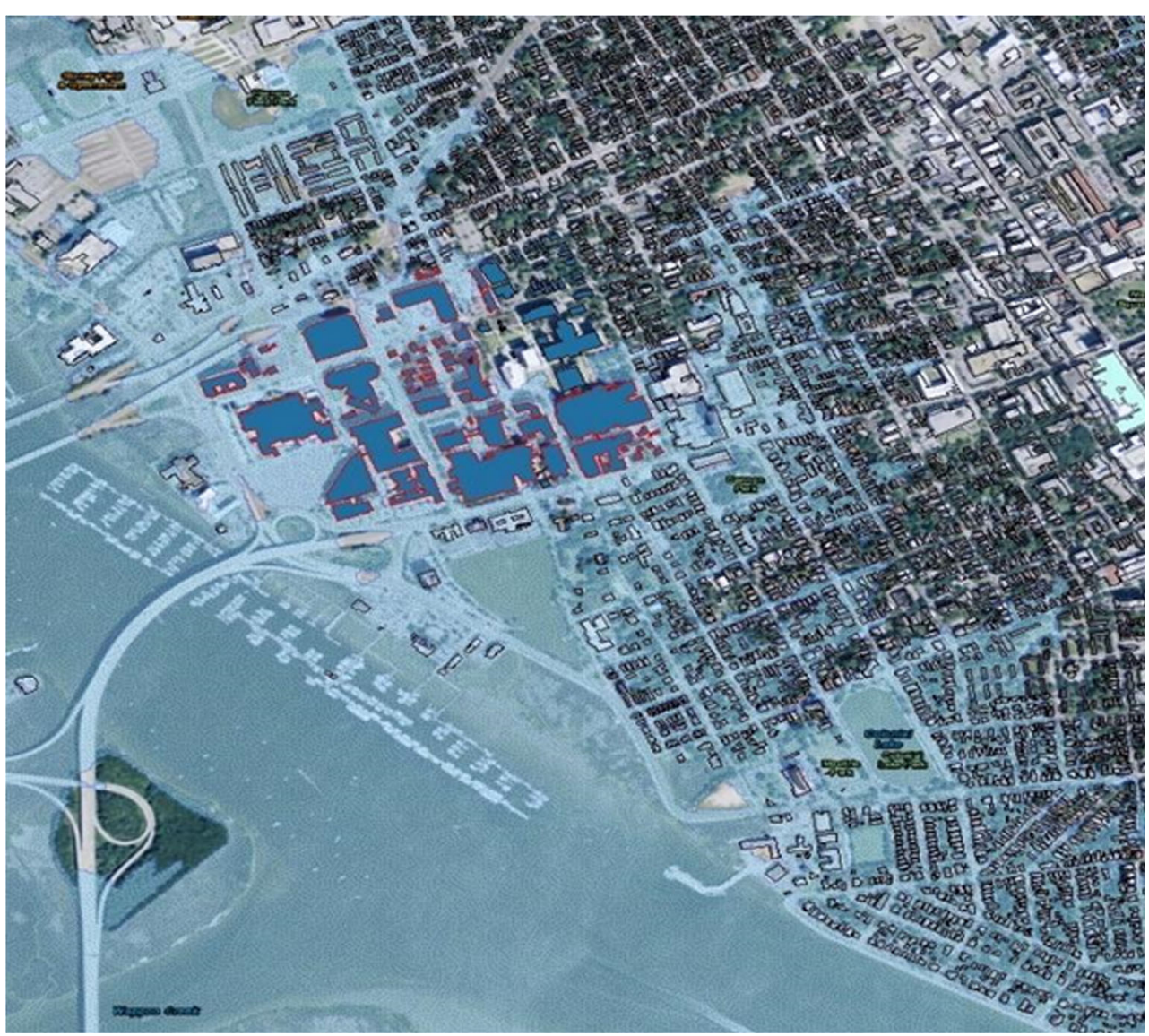

public health is vulnerable to the adverse effects of natural disasters which break the prior predictive pattern of normalcy. There has been an increase in the vulnerability of public health to weather-related natural disasters in recent decades, the same time period when the global climate has been rapidly changing (Fig. 4).

There is a general lack of awareness among hospital administrators and decision-makers concerning environmental vulnerabilities, including climate hazards and weatherrelated risks (e.g., heavy rainfall event). Moreover, coastal hospitals rely on out-dated FEMA Flood Insurance Rate Maps from the 1970s and 1980s to assess flood hazards in their service area [101]. Despite the fact that past catastrophic flooding events have increased situational awareness, there

Table 3 South Carolina's Healthcare facilities exposure metric resulting from four scenarios of an increase in global mean sea-level rise (GMSLR)

\begin{tabular}{ll}
\hline Sea-level rise (ft) & Number of healthcare facilities impacted \\
\hline 1 & 0 \\
2 & 3 \\
3 & 51 \\
4 & 68 \\
\hline
\end{tabular}

are still gaps in understanding and preparing for hospital vulnerability to climate-related changes in extreme events. The Medical University of South Carolina (MUSC) is an ideal case study to perform a climate change and health vulnerability assessment for a coastal hospital to identify and prioritize climate-sensitive health conditions in response to extreme heat or heavy precipitation events. Such a process would adapt Ebi et al. [59] steps in assessing vulnerability by performing the steps in Table 4.

There is a lack of understanding within the public health community about the epidemiological tools which are available to assist local communities in their preparations for, responses to, and recovery from weather-related disasters which are becoming more frequent and severe due to climate change. Such tools have been developed and improved by the National Center for Environmental Health (NCEH) within the US Centers for Disease Control and Prevention (CDC) over the course of the past 20 years. These include epidemiological tools to assist with disease surveillance, outbreak investigations, disease clusters, exposure registries, and public health intervention and evaluation studies. Furthermore, the need for a mobile research capability during disaster response and recovery has been well described. Important research questions have gone unanswered after past weather-related disasters because 


\section{a) Global Changes in Climate $\longrightarrow$ b) Weather-related natural disasters $\rightarrow$ C) Threats to public health}

Fig. 4 Logic model of a climate change and public health logic model

research protocols and funding have not been available in the immediate post-disaster timeframe. As a result, in 2013, the Director of the National Institute of Health (NIH) and the Director of the National Institute for Environmental Health Sciences (NIEHS) provided funding to NIEHS to develop a disaster research response capability - the NIH Disaster Research Response (DR2) program [102]. The scope of this program includes the establishment of an external network of trained researchers/research organizations, the establishment of trained readily available researchers, the identification and prioritization of key environmental health clinical research questions, the development of pre-written and approved research protocols, and the development of publicly accessible data collection tools. In summary, both the NIEHS and the NCEH have developed robust tools and templates applicable to the setting of weather-related disasters, including both research and practice-based tools [54, 58, 66•, 102-109]. More information can be found within their on-line resources. There is a need for greater outreach within the public health community to increase awareness of the existing disaster epidemiology tools which are available for applications within disaster preparedness planning exercises at the local levels.

Climate change serves as a threat multiplier by which existing community-level health disparities, antiquated critical infrastructures for transportation, water, food distribution, communication, as well as other vulnerabilities related to social and environmental determinants of health (e.g., poverty, housing stock, access to healthcare, food security) are amplified, accelerated, or worsened and typically co-occur in the event of a weather-related disaster. Cities around the nation are

Table 4 Steps in developing a vulnerability assessment within a local healthcare system [59]

1. Determine the scope of the vulnerability assessment

2. Describe the current distribution and burden of climate-sensitive health conditions

3. Identify hospital-wide strategies, policies, and measures that reduce the burden of climate-sensitive health conditions

4. Examine the health implications of the potential impact of climate variability and change on the healthcare system

5. Estimate the projected health impact using scenario modeling of future climate change, population changes, and other critical factors and quantify the uncertainty

6. Synthesize the results by outlining gaps in preparedness and prioritize health system planning efforts in the near (5-10 years) or longer term (20+ years)

7. Identify additional community adaptation measures and policies to reduce the negative health effects of extreme events in coastal areas already working to assess their vulnerability and resilience to weather-related disasters by including climate change in emergency preparedness plans and developing adaptation strategies, as well as equipping local hospitals, health departments, and other critical public health systems with climate information. But more work is needed and public health funding is lagging to support local and state-level efforts in preparing for and adapting to weather-related disasters in the context of a changing climate. We propose the following actionable health-based adaptation strategies to strengthen the existing public health infrastructure and to promote public health resilience at the level of the individual, community, and critical healthcare systems:

Public Health Adaptation Strategy 1. Equip local public health departments with the tools and knowledge to systematically perform county-level vulnerability assessments for weather-related disasters, with a particular focus on employing a strengths-based approach to identifying and leveraging community-wide strengths in planning efforts. This process should involve a range of multi-sector stakeholders in government, industry, research, emergency response, healthcare, and public health and involve iterative scenario planning exercises on an annual or semi-annual basis to update disaster preparedness and response plans to weather-related disasters and health emergencies.

Public Health Adaptation Strategy 2. Identify and incorporate climate-sensitive health outcomes in existing local and state-based disease surveillance efforts to monitor health effects before, during, and after a weather-related disaster. More research is needed to examine climatesensitive health outcomes before, during, and after these weather-related disaster events, particularly those that disproportionately affect vulnerable subgroups. Climate-sensitive health outcomes can also be used to inform the development of early detection and warning systems to ensure equitable response and recovery efforts among the most vulnerable members of a community.

Public Health Adaptation Strategy 3. Develop a metric to quantify the severity of weather-related disasters at the local level and explore the non-monotonic and spatiotemporal health impacts of these events. To date, the public health community has done a great job at describing the impacts of climate change on health, but more work is needed to quantify the population-level impacts on health for cities, states, and regional planning and adaptation efforts. A systems-thinking approach should be 
employed that incorporates potential adaptation strategies into predictive or simulation models to better understand cost-effective leverage points, as well as inform viable near and long-term priority planning for population-based interventions and health policies.

Public Health Adaptation Strategy 4. Foster innovative community-level engagement strategies to increase science literacy around the health impacts of weatherrelated disasters. Engagement efforts will involve creating innovative platforms and opportunities to hear from affected community members concerning the ways in which they are directly being impacted by climate change, as well as identify grassroots level communication strategies to ensure that relevant information and resources are effectively being distributed within a community. More research is needed to develop evidencebased climate and health educational modules to enhance climate literacy in the healthcare professional and public health workforce. By collecting shared stories and building partnerships, the public health community can better assess community support for the creation and implementation of sustainable adaptation plans.

Public Health Adaptation Strategy 5. Conduct local health impact assessments (HIAs) to evaluate proposed weather-related disaster adaptation policies. More research is needed to develop best practices and systematically evaluate the benefits of climate adaptation solutions on the health and well-being of the local community. HIAs will also provide a mechanism to determine return on investments for green solutions to mitigate climate change risks and help communities to better prepare and recover from weather-related disasters. As a byproduct of these evaluation activities, public health authorities will be able to assess the political will at the local and state level to address climate change with the added co-benefit of providing the evidence base behind green solutions to mobilize additional investments to confront climate change at the local, state, and national levels.

\section{Conclusions}

Given that global climate change is a clear documented threat to public health, what then are we within the public health community to do to mitigate this public health threat? There are myriad public health threats from global climate change. However, we have chosen to focus our discussion on the most prominent public health threat which the public health community has the most potential to help mitigate weather-related disasters. Weather-related disasters can kill, sicken, and injure thousands of people within a very short period of time. Public health programs routinely prepare for such disasters. But are we collectively preparing for them sufficiently? What are our assumptions of the potential threats? If the disaster planning premise is the climactic status quo then no, risk predictions based on past patterns are insufficient. The climate is changing, and so are the patterns of weather-related natural disasters. Our population health disaster preparedness programs need to be adapted to address the increasing risks to local public health resulting from our changing climate.

Acknowledgments We would like to thank William Clark, an intern with the Cooperative Institute for Climate and Satellites - North Carolina, for his flooding scenario analysis of the Medical University of South Carolina in Charleston, South Carolina. This study was funded in part by the Intramural Program of the NIH, National Institute of Environmental Sciences (ZO1 ES 102945).

\section{Compliance with Ethical Standards}

Conflict of Interest J.R., E.R.S., M.H., R.K.K., and J.P. declare no conflict of interest.

Human and Animal Rights and Informed Consent This article does not contain any studies with human or animal subjects performed by any of the authors.

\section{References}

Papers of particular interest, published recently, have been highlighted as:

- Of importance

•. Of major importance

1. NASA. Global Climate Change, Vital Signs of the Planet. 2018; https://climate.nasa.gov/. Accessed 08/30/2018, 2018.

2. Melillo JM, Richmond T, Yohe GW. Climate Change Impacts in the United States: The Third National Climate Assessment. US GCRP; 2014:842.

3. Burke TA, Fox MA. Global to local: public health on the front lines of climate change. Am J Public Health. 2018;108(S2):S74 5.

4. Frumkin H, Hess J, Luber G, Malilay J, McGeehin M. Climate change: the public health response. Am J Public Health. 2008;98(3):435-45.

5. Frumkin $\mathrm{H}, \mathrm{McMichael}$ AJ. Climate change and public health: thinking, communicating, acting. Am J Prev Med. 2008;35(5): 403-10.

6. Hughes F, Hodkinson J, Montgomery H. Tropical cyclones and public health: how climate change is driving increasingly extreme weather - an essay by Fintan Hughes, Jack Hodkinson, and Hugh Montgomery. BMJ. 2017;359:j4908.

7. Sim F, Mackie P. Climate change, hurricanes and public health. Public Health. 2017;152:A1-2.

8. IPCC, Climate Change 2014. Synthesis Report. Contribution of Working Groups I, II and III to the Fifth Assessment Report of the Intergovernmental Panel on Climate Change. In: Core Writing Team, RK Pachauri and LA Meyer editors. Geneva: IPCC; 2014. p. 151. 
9. McIver L, Kim R, Woodward A, Hales S, Spickett J, Katscherian $\mathrm{D}$, et al. Health impacts of climate change in Pacific island countries: a regional assessment of vulnerabilities and adaptation priorities. Environ Health Perspect. 2016;124(11):1707-14.

10. Stocker T, Qin D, Plattner G-K, et al. Climate change 2013: the physical science basis. Cambridge: Cambridge University Press; 2014.

11. Becker M, Meyssignac B, Letetrel C, Llovel W, Cazenave A, Delcroix T. Sea level variations at tropical Pacific islands since 1950. Glob Planet Chang. 2012;80:85-98.

12. Parris A, Bromirski P, Burkett V, Cayan D, Culver M, Hall J, Horton R, Knuuti K, Moss R, Obeysekera J, Sallenger A, Weiss J. Global sea level rise scenarios for the US National Climate Assessment. NOAA Tech Memo OAR CPO-1. 2012. p. 37.

13. Program USGCR. Climate change impacts in the United States, highlights: U.S. national climate assessment. Washington, DC: U.S. Government Printing Office; 2014. http://purl.fdlp.gov/ GPO/gpo48681, http://nca2014.globalchange.gov/downloads, https://bookstore.gpo.gov/products/sku/003-300-00013-7, http:// utils.louislibraries.org/cgi-bin/lz0050.x?sitecode=LAVW?http:// purl.fdlp.gov/GPO/gpo48681

14. DeConto RM, Pollard D. Contribution of Antarctica to past and future sea-level rise. Nature. 2016;531(7596):591-7.

15. Watts N, Amann M, Ayeb-Karlsson S, Belesova K, Bouley T, Boykoff M, et al. The Lancet Countdown on health and climate change: from 25 years of inaction to a global transformation for public health. Lancet. 2018;391(10120):581-630.

16. Watts N, Adger WN, Ayeb-Karlsson S, Bai Y, Byass P, CampbellLendrum D, et al. The Lancet Countdown: tracking progress on health and climate change. Lancet. 2017;389(10074):1151-64.

17. Hanson S, Nicholls R, Ranger N, Hallegatte S, Corfee-Morlot J, Herweijer C, et al. A global ranking of port cities with high exposure to climate extremes. Clim Chang. 2011;104(1):89-111.

18. Hallegatte S, Green C, Nicholls RJ, Corfee-Morlot J. Future flood losses in major coastal cities. Nat Clim Chang. 2013;3(9):802-6.

19. Nicholls RJ, Hanson SE, Lowe JA, Warrick RA, Lu X, Long AJ. Sea-level scenarios for evaluating coastal impacts. WIREs Clim Change. 2014;5(1):129-150. https://doi.org/10.1002/wcc.253

20. Kunkel KE, Stevens LE, Stevens SE, et al. Regional climate trends and scenarios for the U.S. National Climate Assessment, vol. 142. Silver Spring: NOAA; 2013. p. 77.

21. Ingram KT, Dow K, Carter L, Anderson J, Sommer EK, (Eds.). Climate of the Southeast United States: variability, change, impacts, and vulnerability. Washington DC: Island Press; 2013. p. $1-342$.

22. Church JA, Aarup T, Woodworth PL, Wilson WS, Nicholls RJ, Rayner R, ... \& Blewitt G. Sea-level rise and variability: synthesis and outlook for the future Understanding sea-level rise and variability. 2010;402-419.

23. Meehl GA, Stocker TF, Collins WD, Friedlingstein P, Gaye AT, Gregory JM, Kitoh A, Knutti R, Murphy JM, Noda A, Raper SCB, Watterson IG, Weaver AJ, Zhao Z-C. Global climate projections. In: Solomon S, Qin D, Manning M, Chen Z, Marquis M, Averyt KB, Tignor M, Miller HL, editors. Climate Change 2007: The Physical Science Basis. Contribution of Working Group I to the Fourth Assessment Report of the Intergovernmental Panel on Climate Change. Cambridge and New York: Cambridge University Press; 2007.

24. Kunkel K, Bromirski P, Brooks H, et al. Observed changes in weather and climate extremes. Weather and Climate Extremes in a Changing Climate: Regions of Focus: North America, Hawaii, Caribbean, and US Pacific Islands. 2008;3:35-80.

25. Titus JG, Anderson KE. Coastal sensitivity to sea-level rise: a focus on the mid-Atlantic region, vol. 4: Government Printing Office; 2009.
26. Nicholls RJ, Wong PP, Burkett VR, Codignotto J, Hay J, McLean $\mathrm{R}$, Ragoonaden S, and Woodroffe CD, Coastal systems and lowlying areas, In: Parry ML, Canziani OF, Palutikof JP, van der Linden PJ, Hanson CE, editors. Climate change 2007: impacts, adaptation and vulnerability. Contribution of Working Group II to the fourth assessment report of the Intergovernmental Panel on Climate Change. Cambridge: Cambridge University Press; 2007. p. 315-356.

27. NOAA. National Coastal Population Report: Population Trends from 1970 to 2010. National Oceanic and Atmospheric Administration, Department of Commerce; 2013.

28. Kildow JT, Colgan CS, Scorse JD, Johnston P, Nichols M. State of the U.S. Ocean and Coastal Economies 2014. Paper presented at: State of the US Ocean and Coastal Economies; March 7, 2014, 2014; Monterey, CA.

29. Wilson SG, Fischetti TR. Coastline Population Trends in the United States: 1960 to 2008, Population Estimates and Projections. In: Commerce ESA, editor. . Washington, DC: U.S. Census Bureau; 2010.

30. Lane K, Charles-Guzman K, Wheeler K, Abid Z, Graber N, Matte T. Health effects of coastal storms and flooding in urban areas: a review and vulnerability assessment. J Environ Public Health. 2013;2013:913064.

31. Alderman K, Turner LR, Tong S. Floods and human health: a systematic review. Environ Int. 2012;47:37-47.

32. Jagai JS, Li Q, Wang S, Messier KP, Wade TJ, Hilborn ED. Extreme precipitation and emergency room visits for gastrointestinal illness in areas with and without combined sewer systems: an analysis of Massachusetts data, 2003-2007. Environ Health Perspect. 2015;123(9):873-9.

33. Cann KF, Thomas DR, Salmon RL, Wyn-Jones AP, Kay D. Extreme water-related weather events and waterborne disease. Epidemiol Infect. 2013;141(4):671-86.

34. Caminade C, McIntyre MK, Jones AE. Climate change and vector-borne diseases: where are we next heading? J Infect Dis. 2016;214(9):1300-1.

35. Bell JE, Herring SC, Jantarasami L, et al. Impacts of extreme events on human health. Washington, DC: U.S. Global Change Research Program; 2016. p. 99-128.

36. Veenema TG, Thornton CP, Lavin RP, Bender AK, Seal S, Corley A. Climate change-related water disasters' impact on population health. J Nurs Scholarsh. 2017;49(6):625-34.

37. Cuthbertson J, Archer F, Robertson A. Special Report: WADEM Climate Change Position Statement. Prehosp Disaster Med. 2018: $1-4$.

38. Banwell N, Rutherford S, Mackey B, Chu C. Toward improved linkage of disaster risk reduction and climate change adaptation in health: a review. Int J Environ Res Public Health. 2018;15(4).

39.• Banwell N, Rutherford S, Mackey B, Street R, Chu C. Commonalities between disaster and climate change risks for health: a theoretical framework. Int J Environ Res Public Health. 2018;15(3). Puts forth a framework that links disaster risk reduction and climate change adaptation and describes commonalities in health risks.

$40 . \bullet$ Watts N, Amann M, Ayeb-Karlsson S, et al. The Lancet Countdown on health and climate change: from 25 years of inaction to a global transformation for public health. Lancet. 2017. Describes progress towards the recommendations of the 2015 Lancet Commission on Health and Climate Change.

41. Araos M, Austin SE, Berrang-Ford L, Ford JD. Public health adaptation to climate change in large cities: a global baseline. Int J Health Serv. 2016;46(1):53-78.

42. Hashim JH, Hashim Z. Climate change, extreme weather events, and human health implications in the Asia Pacific Region. Asia Pac J Public Health. 2016;28(2 Suppl):8S-14S. 
43. Lee EE, Stewart B, Zha YA, Groen TA, Burkle FM Jr, Kushner AL. Surgical care required for populations affected by climaterelated natural disasters: a global estimation. PLoS Curr. 2016;8.

44. Kraushar ML, Rosenberg RE. A community-led medical response effort in the wake of Hurricane Sandy. Disaster Med Public Health Prep. 2015;9(4):354-8.

45. Adalja AA, Watson M, Bouri N, Minton K, Morhard RC, Toner ES. Absorbing citywide patient surge during Hurricane Sandy: a case study in accommodating multiple hospital evacuations. Ann Emerg Med. 2014;64(1):66-73 e61.

46. Powell T, Hanfling D, Gostin LO. Emergency preparedness and public health: the lessons of Hurricane Sandy. JAMA. 2012;308(24):2569-70.

47. Gotanda H, Fogel J, Husk G, Levine JM, Peterson M, Baumlin K, et al. Hurricane Sandy: impact on emergency department and hospital utilization by older adults in Lower Manhattan, New York (USA). Prehosp Disaster Med. 2015;30(5):496-502.

48. Verni C. A hospital system's response to a hurricane offers lessons, including the need for mandatory interfacility drills. Health Aff (Millwood). 2012;31(8):1814-21.

49. Kaiser Permanente. Kaiser Permanente Hazard Vulnerability Analysis (HVA) Tool. 2017. https://www.calhospitalprepare.org/ hazard-vulnerability-analysis. Accessed 27 Oct 2018.

50. Campbell P, Trockman SJ, Walker AR. Strengthening hazard vulnerability analysis: results of recent research in Maine. Public Health Rep. 2011;126(2):290-3.

51. ASPR. In: Office of the Assistant Secretary for Preparedness and Response HPP, editor. Healthcare Preparedness Capabilities: National Guidance for Healthcare System Preparedness: national guidance for healthcare system preparedness. Washington, DC: US DHHS; 2012.

52. Haimes YY. On the definition of resilience in systems. Risk Anal. 2009;29(4):498-501.

53. Barbisch DF, Koenig KL. Understanding surge capacity: essential elements. Acad Emerg Med. 2006;13(11):1098-102.

54. Schnall A, Nakata N, Talbert T, Bayleyegn T, Martinez D, Wolkin A. Community Assessment for Public Health Emergency Response (CASPER): an innovative emergency management tool in the United States. Am J Public Health. 2017;107(S2):S186-92.

55. Wolkin A, Schnall AH, Law R, Schier J. Using poison center data for postdisaster surveillance. Prehosp Disaster Med. 2014;29(5): $521-4$.

56. Malilay J, Heumann M, Perrotta D, Wolkin AF, Schnall AH, Podgornik MN, et al. The role of applied epidemiology methods in the disaster management cycle. Am J Public Health. 2014;104(11):2092-102.

57. Buttke D, Vagi S, Schnall A, Bayleyegn T, Morrison M, Allen M, et al. Community Assessment for Public Health Emergency Response (CASPER) one year following the Gulf Coast oil spill: Alabama and Mississippi, 2011. Prehosp Disaster Med. 2012;27(6):496-502.

58. Issa A, Ramadugu K, Mulay P, Hamilton J, Siegel V, Harrison C, et al. Deaths related to Hurricane Irma-Florida, Georgia, and North Carolina, September 4-October 10, 2017. MMWR Morb Mortal Wkly Rep. 2018;67(30):829-32.

59. Ebi KL, Kovats RS, Menne B. An approach for assessing human health vulnerability and public health interventions to adapt to climate change. Environ Health Perspect. 2006;114(12):1930-4.

60. Ebi KL, Lewis ND, Corvalan C. Climate variability and change and their potential health effects in small island states: information for adaptation planning in the health sector. Environ Health Perspect. 2006;114(12):1957-63.

61. Ebi KL, Mills DM, Smith JB, Grambsch A. Climate change and human health impacts in the United States: an update on the results of the U.S. national assessment. Environ Health Perspect. 2006;114(9):1318-24.
62. Keim ME. Preventing disasters: public health vulnerability reduction as a sustainable adaptation to climate change. Disaster Med Public Health Prep. 2011;5(2):140-8.

63. Keim ME. Building human resilience: the role of public health preparedness and response as an adaptation to climate change. Am J Prev Med. 2008;35(5):508-16.

64. Marinucci GD, Luber G, Uejio CK, Saha S, Hess JJ. Building resilience against climate effects - a novel framework to facilitate climate readiness in public health agencies. Int J Environ Res Public Health. 2014;11(6):6433-58.

65. Ganesh C, Smith JA. Climate change, public health, and policy: a California case study. Am J Public Health. 2018;108(S2):S114-9.

66. Moulton AD, Schramm PJ. Climate change and public health surveillance: toward a comprehensive strategy. J Public Health Manag Pract. 2017;23(6):618-26. Provides an assessment of current public health surveillance capacity in the U.S., as well as outlines proposed indicators for public health surveillance indicators related to climate change.

67. Smith JA, Vargo J, Hoverter SP. Climate change and public health policy. J Law Med Ethics. 2017;45(1_suppl):82-5.

68. Hathaway J, Maibach EW. Health implications of climate change: a review of the literature about the perception of the public and health professionals. Curr Environ Health Rep. 2018;5(1):197204.

69. Curtis S, Fair A, Wistow J, Val DV, Oven K. Impact of extreme weather events and climate change for health and social care systems. Environ Health. 2017;16(Suppl 1):128.

70. Smith EC, Burkle FM, Aitken P, Leggatt P. Seven decades of disasters: a systematic review of the literature. Prehosp Disaster Med. 2018;33(4):418-23.

71. Bell JE, Brown CL, Conlon K, Herring S, Kunkel KE, Lawrimore $\mathrm{J}$, et al. Changes in extreme events and the potential impacts on human health. J Air Waste Manage Assoc. 2018;68(4):265-87.

72. Svendsen ER. Disaster epidemiology: assessing the health impacts of environmental public health disasters. J Natl Inst Public Health. 2018;67(1):123-32.

73. PubMed Help. 2005. https://www.ncbi.nlm.nih.gov/books/ NBK3827/.

74. Savoia E, Testa MA, Biddinger PD, Cadigan RO, Koh H, Campbell $\mathrm{P}$, et al. Assessing public health capabilities during emergency preparedness tabletop exercises: reliability and validity of a measurement tool. Public Health Rep. 2009;124(1):13848.

75. Jones M, O'Carroll P, Thompson J, D'Ambrosio L. Assessing regional public health preparedness: a new tool for considering cross-border issues. J Public Health Manag Pract. 2008;14(5): E15-22.

76. Maurin O, Bignand M, Jost D, Travers S, Raclot S, Trichereau J, et al. Usefulness of a multiplying factor in predicting the final number of victims during a mass casualty incident. Eur J Emerg Med. 2017;24(5):377-81.

77. Espinoza Espinoza SE, Vivaceta De la Fuente AE, Machuca Contreras CA. Valparaiso's 2014 Fire: evaluation of environmental and epidemiological risk factors during the emergency through a crowdsourcing tool. Disaster Med Public Health Prep. 2017;11(2):239-43.

78. Cannon M, Roitman R, Ranse J, Morphet J. Development of a mass-gathering triage tool: an Australian perspective. Prehosp Disaster Med. 2017;32(1):101-5.

79. Rydberg H, Marrone G, Stromdahl S, von Schreeb J. A promising tool to assess long term public health effects of natural disasters: combining routine health survey data and geographic information systems to assess stunting after the 2001 earthquake in Peru. PLoS One. 2015;10(6):e0130889.

80. Lee C, Doocy S, Deli A, Kirsch T, Weiss W, Robinson C. Measuring impact: a cross-sectional multi-stage cluster survey to 
assess the attainment of durable solutions in post-tsunami Aceh Indonesia. BMC Public Health. 2014;14:1168.

81. Miller JA, Kearney GD, Proescholdbell SK. Surveillance of injuries in Eastern North Carolina following Hurricane Irene using emergency department data. N C Med J. 2013;74(4):272-8.

82. Caamano-Isorna F, Figueiras A, Sastre I, Montes-Martinez A, Taracido M, Pineiro-Lamas M. Respiratory and mental health effects of wildfires: an ecological study in Galician municipalities (north-west Spain). Environ Health. 2011;10:48.

83. Stebbins S, Vukotich CJ Jr. Preserving lessons learned in disease outbreaks and other emergency responses. J Public Health (Oxf). 2010;32(4):467-71.

84. Magill B. The front lines of climate change: Charleston's struggle. Climate Central, vol. 2018. Princeton: Climate Central; 2014.

85. Carter LM, Jones JW, Berry L, et al. Southeast and the Caribbean. In: Melillo JM, Richmond TC, Yohe GW, eds: U.S. Global Change Research Program; 2014:842.

86. Program UGCR. Minimizing the impacts of coastal flooding helps city prepare for sea level rise. In: NOAA NCfEI, editor. US Climate Resilience Toolkit. Asheville: NOAA; 2017.

87. NOAA. Sea level rise and nuisance flood frequency changes around the United States. Silver Spring: National Oceanic and Atmospheric Administration, Department of Commerce; 2014.

88. Case B, Mayfield M. Atlantic Hurricane Season of 1989. Mon Weather Rev. 1990;118(5):1165-77.

89. Staff NRC. Hurricane Hugo, Puerto Rico, the Virgin Islands, and Charleston, South Carolina, September 17-22, 1989. Washington: National Academies Press; 1993. http://public.eblib.com/choice/ publicfullrecord.aspx? $\mathrm{p}=3376913$, http://public.ebookcentral. proquest.com/choice/publicfullrecord.aspx?p=3376913, https:// ebookcentral.proquest.com/choice/publicfullrecord.aspx? $\mathrm{p}=$ 3376913, https://ebookcentral.proquest.com/lib/columbia/detail. action?docID=3376913, https://ebookcentral.proquest.com/lib/ ben/detail.action?docID=3376913

90. Centers for Disease Control and Prevention. Medical examiner/ coroner reports of deaths associated with Hurricane Hugo- South Carolina. MMWR: Morbidity and mortality weekly report. 1989;38(44):754-759.

91. Brewer RD, Morris PD, Cole TB. Hurricane-related emergency department visits in an inland area: an analysis of the public health impact of Hurricane Hugo in North Carolina. Ann Emerg Med. 1994;23(4):731-6.

92. Shannon MP, Lonigan CJ, Finch AJ Jr, Taylor CM. Children exposed to disaster: I. Epidemiology of post-traumatic symptoms and symptom profiles. J Am Acad Child Adolesc Psychiatry. 1994;33(1):80-93.

93. Grant SM, Hardin SB, Pesut DJ, Hardin T. Psychological evaluations, referrals, and follow-up of adolescents after their exposure to Hurricane Hugo. J Child Adolesc Psychiatr Nurs. 1997;10(1): $7-16$.

94. Thompson MP, Norris FH, Hanacek B. Age differences in the psychological consequences of Hurricane Hugo. Psychol Aging. 1993;8(4):606-16.
95. Wang A, Issa A, Bayleyegn T, Noe RS, Mullarkey C, Casani J, et al. Notes from the field: mortality associated with Hurricane Matthew-United States, October 2016. MMWR Morb Mortal Wkly Rep. 2017;66(5):145-6.

96. Waring SC, Brown BJ. The threat of communicable diseases following natural disasters: a public health response. Disaster Manag Response. 2005;3(2):41-7.

97. Ahmed QA, Memish ZA. The public health planners' perfect storm: Hurricane Matthew and Zika virus. Travel Med Infect Dis. 2017;15:63-6.

98. Davis C. Rapid Reaction: Record Rainfall and Flooding Follow Florence. North Carolina Climate Office. Sept 18, 2018; http:/ climate.ncsu.edu/climateblog?id=266.

99. Center NH. Post-tropical Cyclone Public Advisory. Silver Spring: NOAA; 2018.

100. Hoegh-Guldberg O, Jacob D, Taylor M, Bindi M, Brown S, Camilloni I, Diedhiou A, Djalante R, et al. Chapter 3: Impacts of $1.5^{\circ} \mathrm{C}$ global warming on natural and human systems. In: Global Warming of $1.5^{\circ} \mathrm{C}$ an IPCC special report on the impacts of global warming of $1.5^{\circ} \mathrm{C}$ above pre-industrial levels and related global greenhouse gas emission pathways, in the context of strengthening the global response to the threat of climate change. Intergovernmental Panel on Climate Change. 2018.

101. Guenther R, Balbus J. Primary protection: enhancing health care resiliency for a changing climate. Washington D.C.: US DHHS; 2014.

102. Miller A, Yeskey K, Garantziotis S, Arnesen S, Bennett A, O'Fallon L, et al. Integrating health research into disaster response: the new NIH disaster research response program. Int J Environ Res Public Health. 2016;13(7).

103. Luber G, McGeehin M. Climate change and extreme heat events. Am J Prev Med. 2008;35(5):429-35.

104. Williams H, Downes E. Development of a course on complex humanitarian emergencies: preparation for the impact of climate change. J Nurs Scholarsh. 2017;49(6):661-9.

105. Kim S, Kulkarni PA, Rajan M, Thomas P, Tsai S, Tan C, et al. Hurricane Sandy (New Jersey): mortality rates in the following month and quarter. Am J Public Health. 2017;107(8):1304-7.

106. Iskander J, Rose DA, Ghiya ND. Science in emergency response at CDC: structure and functions. Am J Public Health. 2017;107(S2):S122-5.

107. Eidson M, Clancy KA, Birkhead GS. Public health climate change adaptation planning using stakeholder feedback. J Public Health Manag Pract. 2016;22(1):E11-9.

108. Kurkjian KM, Winz M, Yang J, Corvese K, Colón A, Levine SJ, et al. Assessing emergency preparedness and response capacity using community assessment for public health emergency response methodology: Portsmouth, Virginia,2013. Disaster Med Public Health Prep. 2016;10(2):193-8.

109. Hunter MD, Hunter JC, Yang JE, Crawley AW, Aragon TJ. Public health system response to extreme weather events. J Public Health Manag Pract. 2016;22(1):E1-10. 